EESTI RAKENDUSLINGVISTIKA ÜHINGU AASTARAAMAT 1 (2004), 187-207

\title{
INGLISE-EESTI TEHNIKATÕLKE VIGADE LIIGID JA PÕHJUSED
}

\author{
ANDRES VALDRE
}

Ülevaade. Üks põhjusi, miks tõlge ei vasta algupärandile, võib olla tõlkeviga ehk olukord, kus tõlkeprotsess on olnud häiritud. Enamasti tekivad tõlkevead tõlkija süül, kui tõlkimisel jääb midagi vajalikku tegemata. Tavaliselt tekivad vead lähtetekstist arusaamisel ja sihtkeeles väljendumisel.

Käesolevas reaalsetel toimetamisnäidetel põhinevas töös on vead jaotatud 8 liigiks. Nendel on eritletud 5 liiki objektiivseid (tõlkijast sõltumatuid) veapõhjusi ning 10 liiki subjektiivseid (tõlkijast sõltuvaid) veapõhjusi.

Võtmesõnad: tõlkimine, tehnikatõlge, tõlkevead, tõlkevigade põhjused, inglise keel, eesti keel

\section{Sissejuhatus}

Mis on tõlkeviga? Miks need tekivad? Milliseid vealiike on olemas? Kuidas saab neid vältida?

Tõlkimine võib tunduda lihtne ainult inimese jaoks, kes ei ole tõlkimisega tegelenud. Tundmus, et osatakse mingit keelt, hajub sedamaid, kui sellesse keelde tõlkida ja lasta tõlge asjatundjal üle vaadata. Keel on keeruline süsteem ja eri keeled on erinevad. Mis on ühes keeles loomulik või reeglikohane, on teise keelde otsetõlgituna väga sageli ebaloomulik või reeglivastane.

Tõlkeviga on olukord, kui tõlge ja algupärand ei vasta tõlkimisel tekkinud häirete tõttu üksteisele. Neid häireid võivad põhjustada tõlkijast sõltumatud tegurid, nagu arusaamatu tõlkeülesanne või sõnastikuviga, kuid enamasti on põhjus tõlkijas, kes on jätnud midagi tegemata. Sagedai- 
mad põhjused on seotud tõlkimisprotsessi alguse ja lõpuga - lähtetekstist arusaamise ja sihtkeeles väljendumisega.

Käesoleva artikli aluseks olev konverentsiettekanne oli vahekokkuvõte autori magistriprojektist "Inglise-eesti tehnikatõlke vead" (Valdre 2004). Probleemistiku käsitlus muutus töö käigus esialgsest selgemaks ja täpsemaks ning need muudatused on tagasivaatena sisse kirjutatud ka siia artiklisse.

Olles leivaametis tõlkebüroo tõlkija-toimetajana, enamasti just viimatinimetatu ülesannetes, puutun kokku väga mitmekesiste tarbetõlgetega. Mõnes on vigu rohkem, mõnes vähem, kuid pikapeale ilmneb, et need vead järgivad teatud sarnaseid malle. Autentseid veanäiteid kogunes magistriprojekti valmimiseni 918 (toimetamisel parandatud lauset või fraasi). Et olen hariduselt insener, on teemavaldkond tavaliselt tehnikatõlge laiemas ja kitsamas mõttes. Veanäidete keelesuuna valiku tingis see, et valdav osa minu tööst on inglise-eesti tõlkimine või toimetamine.

Artiklis toodud veanäited ei esinda valmis tõlgete tegelikku kvaliteeti (või selle puudumist), sest need on leitud toimetamisel ja ära parandatud.

\section{Tehnikatôlge}

Tehnikatõlge laiemas mõttes on see tarbetõlke osa, mis jääb üle õigus- ja majandustõlkest. Peale otseselt tehnika (st tehnikatõlge kitsamas mõttes) hõlmab see ka muid täppis-, loodus- ja rakendusteadusi - käesoleva töö näitekogus keskkonnakaitset, ohutust, meditsiini, arvutiasjandust, raudteetehnikat, materjaliteadust, automaatikat, elektroonikat ja lennundust; ning veidi siiski ka poliitikat, majandust ja õigust, sest piirid tõlkeliikide vahel on hägused. Peale tarbetõlke esineb tehnikatõlke elemente (st tekstilõike, mis vajavad käsitlemist tehnikatõlkena) ka muudes tõlkeliikides, nt aime- ja esseistikatõlkes.

Tehnikatõlke kohta kasutatakse eesti keeles sageli otsetõlkena ka võõrkeeltest laenatud nimetust tehniline tõlge. Eesti keele reeglite järgi on see väljend tehnikatõlke tähenduses ebatäpne, sest viitab tõlke omadusele (tõlgitakse tehniliselt?), mitte tõlkimise teemavaldkonnale. Inglise technical translation on mitme tähendusega: 'tehnikatõlge', 'tehniline tõlge', 'tõlkimise tehniline kulg' jt. Sõnaosiste äravahetamisel saab sõna tõlketehnika, mis tähistab tõlkimismenetlusi ja tõlkimise tehnilisi abivahendeid. 
Tüüpiline tehnikatekst - nii kitsamas kui laiemas mõistes - on isikupäratult kirjutatud ja keeleliselt üsna vaene, mis mõneti lihtsustab selle tõlkimist vormilisest küljest. Tekstid võivad olla üldkeelelähedased või täppistekstid, mida on vaja tõlkida eri strateegiatega: jutustavaid üldkeelelähedasi tekste (nt tootetutvustusi, üldkirjeldusi) saab tõlkida vabamalt (mõttetõlge), kirjeldavaid täppistekste (nt seadmete juhtimisjuhiseid, tehnilisi andmeid) tuleb tõlkida tekstilähedasemalt.

Loomulikult on tõlkimisel vaja peale lähtekeelsete sõnade grammatika mõistmise saada aru ka nendega kirjapandud mõttest. Seda võiks nimetada kahetasandiliseks tõlkimiseks, kus esimene tasand oleks grammatiline (sõnad) ja teine sisuline (mõte). Eriti tähtis on see tehnikateksti edukal tõlkimisel. Tehnikatõlke alla kuulub väga palju valdkondi ja samad sõnad võivad tähendada eri valdkondades eri mõtet, mille mittemõistmine tekitab tõlkevigu.

Tehnikatõlke maht on viimase paarikümne aastaga märkimisväärselt suurenenud. Kogu maailmas on tõlketegevuse mahu suurenemise tinginud kolm põhitegurit: 1) üleilmastumine, 2) turumuutused ja kaubavahetuse mahu suurenemine ning 3) arvutitehnika levik (sh Internet) (Ørsted 2001: 440). Eestis on tõlkimise, eriti inglise-eesti tõlgete maht viimase viieteistkümne aasta jooksul pidevalt kasvanud (EE 2002: 525). Tõlketurg on kirju ja tõlgete kvaliteet paraku samuti. Võib öelda, et hoolimata elukutseliste tõlkijate suhteliselt suurest arvust (üle Euroopa Liidu keskmise, mis on u 380 tõlkijat miljoni elaniku kohta (Ørsted 2001: 441)) teevad üsna suure osa tõlkeid tellija "võõrkeelt õppivad noored sugulased" - nagu seda tõlkimisturu kohta üldse täheldas Eugene Nida (2000) - või teevad turustusfirmad vajalikud tõlketööd ise, halvemal juhul eemaletõukavate tulemustega. Tarbijakaitseseaduse $\S 6$ kehtestab küll eestikeelse kasutusjuhendi nõude (Tarbijakaitseseadus 2004), kuid tihti jääb kahtlaseks, kuivõrd on tootega kaasnev juhend ikka eesti keeles.

Tõlkekvaliteedi määrab hulk tegureid, millest põhilisim on tõlkija oskuslikkus. Oskustekstide täpse tõlkimise ülesandele saab läheneda kahest, keelelisest ja sisulisest küljest, mille tulemuseks oleks puhtalt keelepõhine ja puhtalt sisupõhine tõlge. (Ahvatlev, kuid väga ebatäpne oleks neid nimetada vastavalt filoloogi- ja inseneritõlkeks.) Esimese eelis on toimetulemine keelelise küljega, teisel mõttest arusaamisega. Kahjuks on mõlemal ka omad puudused: keelepõhisel tõlkimisel see, et püüdlemine 
keeleliselt täpse tõlke poole viib tihti otsetõlgeteni; sisupõhises tõlkes on jällegi suur tõenäosus tekitada keelevigu.

Humanitaar- ja reaalhariduse lahususe tõttu puudub keeleinimestel sageli ettekujutus tehnikast ja tehnikainimestel keelest. Tulemuseks on see, et keeleosav tõlkija võib jääda hätta spetsiifiliste terminitega või valdkonnateadmistega ja tõlkijale, kellel on head taustateadmised, võivad raskusi tekitada lähtekeele keerulisemad tarindid ja sihtkeele ladusus.

\section{Vealiigid}

Vigade liigitamise eesmärk on tavaliselt olnud praktiline - tõlgete parandamine ja hindamine. Hindamisel saab eri liiki vigadele anda eri kaalukuse ja kogu teksti ulatuses punktid kokku liita. Kuigi seda saab kasutada ka tõlkijale tagasiside andmiseks ja selle kaudu tõlkija arendamiseks (Martínez Melis, Hurtado Albir 2001: 279), väljendab see samas ainult teksti mikrostruktuuri ega hinda teksti kui tervikut.

Kõige põhjalikum tõlkevigade liigitus on välja töötatud Kanadas: CTIC- $i^{1}$ skaala tõlgete parandamiseks ja SICAL-i ${ }^{2}$ skaala tõlgete hindamiseks. Viimane põhineb D. Goudadeci uurimustel, kes on pakkunud välja 675 vealiiki (300 sõnavaraviga ja 375 lauseehitusviga) (samas: 274).

Järgnevalt on esitatud 8 peamist tõlgetes esinenud vealiiki.

\subsection{Sihtkeele vead}

Sihtkeele vigadeks nimetatakse käesolevas töös selliseid vormivigu, mis ei moonuta teksti sisu ja mille tekkimine ei ole tõlkeprotsessi tulemus (st sama hästi võiksid need olla algupärases tekstis). Sihtkeelevead on nt õigekirjavead (sh ühikute ja arvude kirjavead), stampväljendid, võõrmõjulised keelendid ja muud keeleiluvead (vt Liivaku 2001) ning lauseehitusvead (nt ühildumisvead).

Niisugused keelevead on siinkäsitlevatest veatüüpidest kõige kergemad, sest need tavaliselt ei muuda teksti sisu ja neid on muudest vigadest kergem avastada.

Conseil des traducteurs et interprètes de Canada.

Système canadien d'appréciation de la qualité linguistique. 


\subsection{Teema-reema vead}

Teema-reema veaks nimetatud veatüübis eksitakse põhimõtete vastu, kui inglise lause mõtte vormimisel eestikeelseks lauseks ei arvestata erineva lauseehituse tõttu teema ja reema asetusega lauses (st uue teabe esitamist lause lõpus). Üldiselt on teema ja reema korralikus lähtetekstis paigas (1).

(1) Inglise lause: "the aim of which is to apply new findings in technology to industry"

Toortõlge: "mille eesmärgiks on kohaldada tööstustes uusi tehnoloogiaavastusi"

Toimetatud tõlge: "mille eesmärgiks on rakendada uusi tehnoloogiasaavutusi tööstuses"

\subsection{Kollokatsioonivead}

Selles veatüübis on eksitud eesti keelele omaste kollokatsioonide vastu, nt kasutatakse otsetõlkelist omadussõna kohas, kus eesti keeles kasutataks teist omadussõna. See veatüüp ei ole tingimata seotud tõlkimisega, sest esineb tihti ka eestikeelses originaaltekstis, kuid tihti inglise (ja muude) keelte kaudsel mõjul, olles seega ikkagi tõlkeviga.

Üks tüüpilisemaid kollokatsioonivigu on inglise keele mõjul omadussõnade kõrge-madal kasutamine kohas, kus eesti keeles kasutataks pigem omadussõnu suur-väike või nende erimeid. Näiteks Eestis on füüsikuid, kelle arvates saab magnetväli olla kõrge (ja mitte tugev).

Kollokatsioonivigu aitaks vältida hoolikas läbimõtlemine, mida kirjapandud sõnad õigupoolest tähendavad.

\subsection{Stiilivead}

Stiilivigadeks nimetatakse käesolevas töös tõlkevigu, kus tõlke stiil ei sobi - lähteteksti ja tõlke sama eesmärgi korral - kokku lähteteksti vastava osa stiiliga või tekib soovimatu mitmeti mõistmise oht. Stiilivigade hulka kuulub stiilivarjundite ehk registrite vääriti mõistmine või väljendamine.

Stiil oleneb mõningal määral tõlke kasutusotstarbest, mis aga on tehnikatekstidel üldiselt sama kui algupärandil. Seetõttu peaks ka stiil 
jääma tõlkes samaks. Stiiliviga võib olla ülenev või alanev, kus tõlke stiil on lähteteksti stiilist vastavalt kõrgem (harva) või madalam (2).

(2) Inglise lause: "The Brussels gathering was the interim phase of a multistage process."

Toortõlge: "Brüsseli koosistumine tähistab esimest sammu paljuastmelises protsessis."

Toimetatud tõlge: "Brüsseli konverents on esimene samm pikas protsessis."

Sageli kasutatakse tõlkes argikeelt kirjakeele asemel (nt näpp selmet sõrm või mahamüümine selmet müümine).

\subsection{Terminivead}

Kui tõlkija peab ühe valdkonna terminit teise valdkonna terminiks (meenub mikrolaineahjus pöörleva plaadi ajamvõlli nimetamine kardaanvõll) või kasutab mingit terminit süstemaatiliselt valesti (nt ta ei tea, mida see täpselt tähendab), siis on tegemist terminiveaga.

Tõlkija võib terminit üldse mitte ära tunda ja kasutada selle vastena üldkeele sõna (nt arvab inglise mainframe 'suurarvuti' tähendavat põhiraam); või ta ei leia õiget vastet (kuigi see on eesti keeles olemas) ja kirjutab terminivaste asemel pika ümberjutustuse, mis võib olla õige või mitte (nt töojooniste (manufacturing drawings) nimetamine tootmisprotsessi kirjeldav joonis).

Suhteliselt harv (kuid huvitav) on olukord, kus üldkeelesõna tõlgitakse terminiks (nimetaksin seda alaliiki hoog-sees-vigadeks - kui tõlkijal oli erialasõnastiku kasutamise hoog sees), nt arvutitekstis olnud inglise $c h e c k$ for late updates tõlkimine fraasiks viimaste uuenduste märkimine, kuigi loogilisem oleks olnud uuenduste kontrollimine.

\subsection{Sõnastusvead}

Puhtal kujul on sõnastusviga selline viga, kus sõnastus on ebakorrektne (nt on sõnajärg vale või sõnastus on kohmakas), kuid lause mõte oluliselt ei muutu (kui see muutub, on tegu loogikaveaga). Erinevalt ülalkirjeldatud sihtkeele vigadest on sõnastusvead tekkinud tõlkeprotsessi käigus (ei ole sihtkeele keelevead). 
Tõlge võib olla kohmakas, nt inglise day and a half oli kord pooleteist päeva asemel tõlgitud kujul päev ja veel pool päeva (see on sisuliselt inglise teksti otsetõlge).

Tõlkes võib tekkida tautoloogia ehk tähendusliiasus, nt up to $12 \%$ oli kord tõlgitud kuni maksimaalselt 12\%, kus üks kahest sõnast on liigne. Sõnaliiasus tuleneb sellest, et inglise keeles on tavaks öelda asju teistmoodi, nt inglase jaoks on täiesti tavaline öelda to switch on or off, place your finger .., kuid oma sõrme rõhutamine on eesti keeles kohatu, sest kelle teise sõrmega ikka nupule vajutatakse.

Sõnastusviga võib olla ka lähtetekstis, nt meenub ühes tekstis seisnud mõttetu up to 3,5 $\mathrm{mm}$ or more. Siin seisab tõlkija küsimuse ees, kas tõlkida sõna-sõnalt kuni 3,5 mm või rohkem või teavitada tekstis olevast mõttetusest tellijat.

\subsection{Otsetõlked}

Otsetõlked on sagedaimad tõlkevead üldse (kogutud vigade hulgast üle poole) ja sisaldavad sageli ka loogikavigu.

Otsetõlke kui vealiigi alaliikideks võivad olla: sõnade otsetõlge ja grammatilise ehituse otsetõlge. Esimeses on lähteteksti fraasi või lause sõnad asendatud sihtkeelsete sõnadega, kuid sihtkeelse teksti grammatiline ehitus on sihtkeeleomane. Teises alaliigis on järele aimatud lähtekeele grammatikat (nt täiendite järjekorda, lauseehitust, suurtähtede ja sidesõnade kasutust, lühendeid või on kasutatud sihtkeele sõnade jaoks tavatut sõnaliiki), kuigi sõnatasandil võib otsetõlge puududa. Need kaks alaliiki võivad esineda ka koos.

Sõnatasandi otsetõlkeid põhjustab suur hulk nn tõlkekarisid, mida tõlkijad tõlgivad pahatihti valesti. Tavalisimad on nt national, standard, traditional, control, technology ja industry. Inglise national on eesti rahvuslik suhteliselt harva, sest eesti keeles tähendab rahvus pigem 'etnost' ja inglise nation pigem 'riiki'. Omadussõnana on standard pigem 'tavaline' kui 'standardne' (kui jutt ei ole standardist). Samuti on traditional pigem 'tavapärane' kui 'traditsiooniline' (kui jutt ei ole traditsioonist). Control on pigem 'ohjamine' kui 'kontrollimine', sest kontrollimine on inglise keeles pigem check - välja arvatud prantslaste kirjutatud ingliskeelsetes eurotekstides (Le mot juste 2002). Viimasel ajal on technology 
vasteks saanud tehnoloogia, hoolimata varasemast vastest tehnika (keda huvitab, mis on tehnika ja mis on tehnoloogia, leiab ammendava selgituse ENE-st ja sama paaril real ÕS 1999-st). Väitega, et tähendus ajapikku muutub ja et õigsuse paneb paika kasutussagedus, ma päris ei nõustu, sest tehnoloogia kasutamine tehnika asemel on toorlaen inglise keelest - kui mingit viga tehakse piisavalt palju, kas siis selle vigasus kaob?

Tõlkekaride üks põhjus on koolist meelde jäänud tähendused ehk sõnastiku esimesed vasted. Nt inglise accidental failure ei pruugi tingimata olla avariiline rike, vaid juhuslik rike, sest sõna accident põhitähendus on 'juhus', mitte ‘õnnetus', nagu koolist võib olla meelde jäänud.

Lähtekeele grammatika otsetõlge on näiteks sõnaliigi otsetõlge kohas, kus eesti keeles kasutataks teist sõnaliiki - inglise is responsible vaste oleks ilusas eesti keeles vastutab, mitte on vastutav, sest tasub meeles pidada, et inglise keeles ei ole eesti sõna vastutama tegusõnalist vastet.

Tõlkija, kes "tõlgib" lähtekeele lühendid seniolematuteks eestikeelseteks lühenditeks, näitab üles hoolimatust teksti kasutaja vastu, kes mõistatuslikust lühendist arusaamiseks peab hulga tarbetut vaeva nägema. Sellises olukorras peab tõlkija endale aru andma, kas tema näpuvaeva kokkuhoid on ikka kokkuhoid õiges kohas. Meenub ühe tõlke suur tabel, mille pooltes ruutudes oli lühend $P N$, mis alles lähemal uurimisel osutus inglise lühendi $N I=$ not indicated tõlkimisel saadud sõnade pole näidatud lühendiks.

\subsection{Loogikavead}

Loogikaviga on selline tõlkimisel tekkinud sõnastusviga, kus mõte muutub (st sisuviga). Sageli (kuid mitte alati) on tegu otsetõlkega. Loogikaviga on varjatud sisuveana kaalukaim tõlkeviga.

Kergeim loogikaviga on veidrate kõrval- või vastandtähenduste tekkimine, nt avage käega värav tähendab ka seda, et värava peal või küljes on käsi (parem oleks avage värav käega) ning tõsine vigastus lubab oletada, et olemas on ka naljakas vigastus (parem oleks raske vigastus). Oma mõju võib avaldada ka mõttepaus, nt reavahetuse sattumine sobimatusse paika.

Kerge loogikaviga on vastuolu kirjutatu ja tegelikkuse vahel, nt activated partial thromboplastin time ei saa olla aktiveeritud osaline 
tromboplastiini aeg, sest aeg ei saa olla aktiveeritud (parem oleks aktiveeritud osaliste tromboplastiinide aeg).

Raske loogikavea võib põhjustada vale sõnajärg (kui tõlkija ei ole aru saanud, millest on jutt), nt underground coal gasification ei või olla maaaluse söe gaasistamine (sest kus mujal kivisütt ikka leidub kui maa all), vaid söe maa-alune gaasistamine.

Korraga otsetõlgete, sõnastusvigade ja loogikavigade hulka kuulub sage vealiik, kus lähtekeele tekst (fraas või rohkem) tõlgitakse sõnasõnalt, kusjuures lähtekeeles on asjal mõte, eestikeelsetel sõnadel omaette on ka mõte, aga kokku on tõlge muutunud loogika väga tugeva väändumise tõttu totruseks. Nt adopted solutions $\sim$ adopteeritud lahendused (pigem rakendatud lahendused; kuigi hea, et ei olnud lapsendatud lahused); portable air conditioner $\sim$ kaasaskantav õhukonditsioneer (pigem teisaldatav või veel paremini teisaldatav kliimaseade); wide range of infectious diseases $~$ lai valik nakkushaigusi (pigem mitmesugused nakkushaigused) jne.

Loogikavigade tekkimist aitab vältida tõlkija silmaring ja kaasamõtlemisoskus - tuleb vaid kirjapandu mõttega üle lugeda ja kontrollida, kas tekstis kirjutatu on võimalik ja kas teksti saab mõista ainult ühte moodi.

\section{Veapõhjused \\ 3.1. Üldist}

Tõlkevead ei teki niisama, kuid nende tekkepõhjusi on uuritud vähem kui vigu endid. PACTE ${ }^{3}$ töörühm eristab lingvistilisi (leksikaalseid, süntaktilisi, tekstilisi), ekstralingvistilisi (kultuurilisi, temaatilisi, entsüklopeedilisi), ülekande- (transfer problems; dünaamilise ekvivalentsi leidmise raskused), psühhofüsioloogilisi (loovuse ja loogilise mõtlemisega seotud) ning professionaalseid ja instrumentaalseid (tõlkeülesandest või dokumendist tingitud probleemid) põhjusi (Martínez Melis, Hurtado Albir 2001: 281).

Käesolevas töös on tõlkevigade tekkepõhjused jaotatud kaheks rühmaks: objektiivseteks ehk tõlkijavälisteks (5 liiki ja 11 alaliiki) ning subjektiivseteks ehk tõlkijaomasteks põhjusteks (10 liiki ja 13 alaliiki). Esimesed on tõlkijast sõltumatud; teised kajastavad seda, mis toimub tõlkija peas (või mis seal toimumata jääb).

3 Process of the Acquisition of Translation Competence and Evaluation. 
Nagu vealiigid, nii kattuvad osaliselt ka vigade tekkepõhjused, sest nende vahel ei ole selgeid piire. Sama vealiigi võib tingida mitu põhjust ja sama põhjus võib tekitada mitut liiki vigu. Oskuslik tõlkija tuleb aga vigade tekkepõhjustega toime.

\subsection{Objektiivsed ehk tõlkijavälised põhjused 3.2.1. Tõlkeülesanne}

Tõlkeülesande (translation brief) all mõeldakse tellija sõnastatud kõiki tõlkimisega seotud asjaolusid; praktikas koosneb tavaliselt ainult tähtajast. Tõlkeülesandest tingitud vead tekivad, kui tõlkeülesanne on puudulik või arusaamatu, ja puudutavad kogu teksti tervikuna. Õnneks kujutavad head tõlkijad - kes teavad, et täpne tõlge ei tähenda sõnasõnalist tõlget ja et lähteteksti sõnadest (kuid mitte mõttest) kaugenemine ei ole veel vabatõlge - endale tavaliselt tõlkides ette, kellele ja misjaoks tõlge on ette nähtud.

\subsubsection{Lähteteksti vähene sidusus}

Korralik tekst peab olema sidus nii süntaktiliselt kui ka semantiliselt. Semantiline sidusus tähendab mõtte järgnevust loogilises järjestuses ja süntaktiline sidusus tähendab selle saavutamise vahendit (Fraser 1998: 7). Tekst võib olla sidus sama teksti ulatuses või tekstide vahel (tekstisisene ja tekstidevaheline sidusus/koherentsus).

Vähese sidususe (ja enamasti puuduva semantilise koherentsusega) tekstid on näiteks segmendid automaattõlke jaoks. Kui nende kasutusjärjekord jääb ka tõlgituna inglise või muu võõrkeele taoliseks, võib arusaadavuse seisukohalt järgneda katastroof. Näiteks teatud sugupuutarkvara kasutajaliidese ühe pealkirja ehitus oli algselt [son] [daughter] [of] [father] [and] [mother]. Kasutusliidese keele vahetamisel kasutatakse vaid teise keele segmente, kuid nende paigutus jääb samaks: nii oli "eestikeelne" pealkiri algselt [poeg]/tütar] [kelle] [isa] [ja] [ema].

Sisuliselt korrektsest lähtetekstist arusaamist võivad takistada ka ebakõla [oletatava] tõlkeülesandega, arusaamatud joonised või nende puudumine ("üks pilt ütleb rohkem kui tuhat sõna") ja lähteteksti keerulisus (nt hiiglapikad keeruliselt liigendatud laused patendikirjeldustes). 


\subsubsection{Lähteteksti vead}

Mõnikord on viga sees juba lähtetekstis ja tõlkija tõlgib täpsuse poole püüeldes selle ka ära (üldjuhul - arvestades tehnikatekstide tavalist kasutusotstarvet - tuleks ilmsed vead ära parandada, soovitatavalt kliendiga nõu pidades). Need võivad olla näiteks vormivead, tekstituvastusel tekkinud vead, loogikavead, stiilivead ja segane sõnastus. Erakordseim tuvastusviga, mida olen näinud, oli ühe inventariloetelu eesti-inglise tõlkes, kus eesti 2 komplekti oli algselt lühendatud $2 \mathrm{kompl}$., mis aga tuvastamisel oli lähtetekstis moondunud vigaseks vormiks 2 kõmpi, misjärel originaalile orjalikult truu tõlkija oli selle ümber pannud kui 2 stilts.

Segase sõnastuse võib tingida sage olukord, kus lähteteksti keel on autorile võõrkeel. Näiteks kirjutasid ühes tarkvarakirjelduses jaapanlased käsiraamatust otsimise kohta paper-based manual search, mille tõlkija oli arvanud paberipõhiseks käsitsiotsinguks. Kahjuks on ebamääraselt sõnastatud ka paljud eurotekstid, udususe vähendamiseks alustas Euroopa Komisjoni tõlkekeskus 1998. aastal kampaaniat "Fight the Fog"4.

Sageli esineb olukord, kus lähtetekst ei ole algtekst, vaid on ise tõlge. Sellise olukorra avastamisel on parim lahendus üritada hankida algtekst ja tõlkida selle järgi, sest varasem tõlkija võib olla samuti teinud vigu ja mitmekordse tõlkimise tulemus võib jääda algtekstist üpris kaugele. Hea tõlkija peaks suutma aimata, mis on liikunud varasema tõlkija peas ja oskama selle põhjal rekonstrueerida oma tõlkesse algteksti mõtte. Nimetaksin sellist tegevust "tekstiarheoloogiaks".

\subsubsection{Sõnastikuvead}

Tõlkevigu võivad tekitada sõnastike aegunud või väärad vasted, ebaadekvaatne koostamismeetod, sihtkeele vastete tegeliku kasutuse eiramine, keele- ja trükivead või olulise vaste puudumine.

Inglise-eesti üldisi tehnikasõnastikke on praegu olemas kaks: TEA kirjastuse "Teaduse ja tehnika seletav sõnaraamat" ja Euroülikooli "Inglise-eesti tehnikasõnaraamat". Mõlemad on ideaalist kaugel, kuid neid saab siiski kasutada, kui teada nende plusse ja miinuseid: esimeses on teemavalik laiem (tehnika, täppis- ja loodusteadused), kuid sellega kaasneb

$4 \quad$ Vt http://europa.eu.int/comm/translation/en/ftfog/. 
vähene sügavus; teine on esinduslik kompaktne inglise-eesti terminivastete kogu, kuid on ainevaldkonniti väga ebaühtlane (sõnastik on mehaaniline, toimetamata ja ebaühtlane segu ainevaldkondade sõnastikest), selles on rohkesti vigu ja sealt puuduvad üldterminid.

Heal tõlkijal peaks olema peas palju rohkem teavet kui sõnastiku kaante vahele mahub, nimelt selle kohta, kuidas sõnad selgeks ja meeldivaks tekstiks kokku käivad (Nida 2000). Keeled ei ole tegelikult sõnastikes, vaid inimeste peas (samas).

\subsubsection{Spellerivead}

Speller ehk arvuti õigekirjakontroll on hea abiline enamiku näpuvigade leidmisel, kuid ainult spellerile lootma jäädes võib sealt läbi lipsata mõni eriti totter näpuviga, kus speller on arvanud sõna korrektsetest osistest koosnevaks liitsõnaks, nt sisendeit $>$ sisendeid, tähistakse $>$ tähistatakse, kaesolev $>$ käesolev, praemale $>$ paremale, liiguba $>$ liigub, võikese $>$ väikese, automatse $>$ automaatse, roitevõrk $>$ toitevõrk, kitselüliti $>$ kaitselüliti ja läbiröökimised > läbirääkimised. Tegu ei ole otseselt mitte põhjuse, vaid tagajärjega (kuid speller takistab selletüübiliste vigade leidmist).

\subsection{Subjektiivsed ehk tõlkijaomased põhjused 3.3.1. Terminipiiri mittetajumine}

Selle põhjuseliigi korral ei tunne tõlkija terminit või selle ulatust ära. Tavaliselt mõjutab põhjus mitmesõnalise termini äratundmist, nt active carbon filter ei ole efektiivne süsifilter, vaid on aktiivsöefilter, ja lead acid cell ei ole pliihappe element, vaid on pliielement ehk pliiaku element.

Peale "tavaliste" terminite mõjutab terminipiiri mitteäratundmine ka süsteemsete terminite ja kinnisväljendite tõlkimist, mille omaalgatusliku tõlkimise asemel tuleb kehtiv vaste järele vaadata. Süsteemsed terminid on näiteks bioloogiliste liikide, anatoomiliste üksuste, haiguste ja ühingute nimetused, kohanimed, standardite ja õigusaktide pealkirjad, ohtlike kemikaalide riski- ja ohutuslaused ning muud tähised. 


\subsubsection{Faktiviga}

Ka selle põhjuse tingib väike silmaring, aga otsesemalt kui terminipiiri tajumata jätmise: teksti õigeks tõlkimiseks on vaja tekstiväliseid teadmisi (st võib juhtuda, et neid teadmisi tõlgitavast tekstist ei saa). Nt Euroopa Liidu asutus European Council ei ole Euroopa Nõukogu (mis on inglise keeles Council of Europe ja ei ole kuidagi seotud ELiga), vaid Euroopa Ülemkogu; UN Charter ei ole ÜRO põhikiri, vaid on ÜRO harta; World War I antitank gun ei olnud oma kontekstis I maailmasõja aegne tankirusikas, vaid I maailmasõja aegne tankitõrjepüss (tankirusikad leiutati alles II maailmasõjas ja õhema soomuse vastu kasutati varem tõesti suurekaliibrilisi tankitõrjepüsse); ja spiders and other insects peaks ämblike ja munde putukate asemel olema pigem ämblikud ja putukad, kuivõrd ämblikud ei ole putukad.

Head tõlkijad on suure silmaringiga inimesed ja neil tekib faktivigu harva. Siin tuleb kasuks spetsialiseerumine teatud valdkonnale, kus aja vältel koguneb rohke teadmistevaru.

\subsubsection{Sarnane võõrsõna}

Sage veaallikas on ahvatlus tõlkida lähtetekstis olev sõna sarnase omakeelse võõrsõnana (või laensõnana). Viga tekib juhul, kui (näiliselt) samatüveliste sõnade tähendus erineb keeleti. Nt hospitals, doctors' practices, radiology institutes vasteks oli tõlkija arvanud haiglad, arstipraksised, radioloogiainstituudid, mis oleks pigem haiglad, arstide vastuvõturuumid, radioloogiaasutused; samuti tihti tõlgitakse sõna silicon 'räni' silikoon, rääkimata juba eksitavatest oksiidinimetustest silica 'ränidioksiid', magnesia 'magneesiumoksiid' ja alumina 'alumiiniumoksiid'. Inglise galvanised on eesti keeli mitte galvaniseeritud (mis üldterminina on inglise keeli plated), vaid tsingitud; ja inglise plastic nimisõnana tähendab eesti keeles plast või plastmass, mitte plastik, mida ÕS 1999 seletab kui plastsuusk. 


\subsubsection{Terminimoodustuse puudulik oskus}

Tõlkevigu võib põhjustada olukord, kus tõlkija ei tea sihtkeele terminimoodustuse reegleid. Sage komistuskivi on inglise täiendite järjekord (mis põhineb veidi teistsugustel reeglitel kui eesti keeles) ja inglise lõppliide -er, mis võib tähendada nii elusat kui elutut, kuid mida sageli tõlgitakse $j a$-liitega (mis enamasti tähendab elusolendit) ning saab oskuskeele jaoks kohatuid tulemusi, nagu traktori korstna otsas olev sädemepüüdja selmet sädemepüüdur või toalaadija selmet toalaadur.

\subsubsection{Vähene lähtekeele oskus}

Levinud on arvamus, et tõlkija ei pea lähtekeelt oskama sügavuti. Ometi võivad vigu tekitada (ja loomulikult tekitavadki) lähtekeele tundmatud sõnad, rasked tarindid, tegusõna ajad, lühendid, tautoloogiaoht, idioomid, metafoorid, tähendusvarjundid, iroonia, eufemismid ja düsfemismid.

Inglise tarindid, mille tõlkimisel on tehtud vigu, on nt a number of 'mitu', at times 'mõnikord', by reference to '(millegi) järgi', mitte viidete järgi), in order to 'millekski', olen näinud selle vastet järjekord - sama tõlkija arvas ka, et in particular tähendab üksikosised, mitte 'eelkõige'), to account for balance, to be subject to ja tingimuslik while.

Tõlkijad, kes ilmselt ülehindavad oma inglise keele oskust, satuvad hätta passiiviga, eristamata seda minevikuvormidest, tõlkides fraasi plug to be removed 'kork tuleb eemaldada' kui kork on eemaldatud, rääkimata tingimuslausete olevikku väljendavast vormist if .. were ..

Tautoloogiaoht on juhul, kui inglise keeles on sõnad laiema tähendusega ja selle piiramiseks kasutatakse lisasõnu, nt paint brush on pigem pintsel kui värvipintsel, sest brush üksi võib tähendada ka 'hari'; samuti on a moment of time pigem hetk kui ajahetk.

Idioome ja metafoore on tehnikatekstides vähe, kuid nende väärtõlkimise oht on siiski olemas. Olgu näiteks tõstukite eripära, kus nii eesmist kui tagumist rattapaari pööratakse samas suunas, nii et tõstuk ei pöördu (mis juhtub siis, kui üks rattapaar jätta pööramata või pöörata rattapaare eri suundades), vaid liigub külitsi; seda nimetatakse inglise keeles $c r a b$ movement. Eesti keeles oleks ilusam külitsiliikumine kui liikumine vähikombel (sest krabi liigub külitsi ja vähk tagurpidi - seda oleks võinud tõlkija arvestada). 


\subsubsection{Loogilise kaasamõtlemise puudumine}

Kui tõlkija ei suuda tekstiga kaasa mõelda, mille tulemusena muutub mõte vastupidiseks või kirjapandud teksti tähendus lahkneb mõeldud tähendusest, on tegemist loogilise kaasamõtlemise puudumisega. $\mathrm{Nt}$ obstacles-plough takistuste äralükkamise ader, pigem vedurisahk; DC $3 \mathrm{kV} \sim$ alalisvool $3 \mathrm{kV}$, pigem alalispinge $3 \mathrm{kV}$, sest volt ei ole vooluühik.

Ka see põhjuseliik tekitab halvimal juhul totrusi, nt human specimens with anti-mouse antibody levels $\sim$ inimeste hiirtevastaste antikehade tasemetega vereproovid (pigem inimpäritoluga proovid, mis sisaldavad hiire antigeenide vastaseid antikehi).

\subsubsection{Ettekujutusvõime puudumine}

See veapõhjus, mis teatud viisil tähendab samuti loogilise kaasamõtlemise puudumist, tekitab vastuolu mõeldu ja kirjutatu olemuse vahel, näiteks ühikute, suuruse või toimimispõhimõtte osas. Meenub tõlkeviga raamatus "Skorzeny erimissioonid", kus ühes kohas kandsid sõdurid kuulipildujat MG 42 (mille mass oli 11 kg), mis oli "tõlgitud" 42-millimeetrise kaliibriga kuulipilduja - see oleks kaalunud vähemalt tonni, kuid tõlkija ei olnud ilmselt ette kujutanud, kui raske selline relv oleks (ja mispärast seda nimetati üldse veel kuulipildujaks, mitte suurtükiks).

Teine ettekujutusvõime puudumise näide oli ühes kliimaseadme paigaldusjuhendis (3).

(3) Inglise lause: "The cassette types air-conditioners can be mounted neatly into a lowered ceiling space as narrow as $25.5 \mathrm{~cm}$, by only one person."

Toortõlge: "Kassett-tüüpi õhukonditsioneere on ühel inimesel võimalik hõlpsasti paigaldada madalama laega ruumidesse piirkõrgusega $25,5 \mathrm{~cm}$." (Siit jääb mulje, et tõlkija arvates saab $25,5 \mathrm{~cm}$ kõrguses ruumis hõlpsasti liikuda!)

Toimetatud tõlge: "Kassett-tüüpi õhukonditsioneere saab paigaldada hõlpsasti ripplae peale isegi siis, kui seal on ainult $25,5 \mathrm{~cm}$ kõrge vaba ruum. Paigaldamiseks on vaja ainult üht inimest.”

Kolmas ettekujutusvõime puudumise näide oli ühe raskeveduri hooldusjuhendi toortõlkes, kus juhiruumi ühe seadme katte kinnitamise (secure) vasteks oli tõlkija kirjutanud seejärel toetage vedur vastu kindlat ja 
tugevat seina. Tõlkija ilmselt ei olnud endale ette kujutanud, kuidas see 200-tonnise veduri puhul võiks välja näha.

\subsubsection{Sõnastike ja terminibaaside sihipäratu kasutamine}

Sõnastike sihipäratu kasutamine on näiteks see, kui sõnastikku kasutatakse võhiklikult, nt võetakse vihjesõnastikust ${ }^{5}$ esimene ettejuhtuv vaste. Peale erivormiliste sõnastike (paberipõhiste, elektrooniliste ja internetipõhiste sõnastike) kehtib sama ka terminibaaside kasutamise kohta, kui sealt on võetud vale termin või sarnane (kuid konteksti sobimatu) termin.

Siia põhjuseliiki kuulub ka teguviis, kui tõlkija jätab miskipärast liigse enesekindluse, sõnastiku või järelevaatamisvõimaluse puudumise või lihtsalt laiskuse tõttu - sõnastikust või terminibaasist järele vaatamata ja eelistab kasutada oma väljamõeldist. Viimaste kasutamine on koht, kus tõlkijad sageli oma fantaasiat kokku ei hoia ega loogilist mõtlemist ilmaasjata kuluta.

Käesolevat liiki veapõhjustest saab hea tõlkija üle laia silmaringi abil. Et inimese pea ei ole kummist ning kõike ei ole võimalik meelde jätta, aitab palju kaasa ka teadmine, kust või kuidas mingi valdkonna termineid saab otsida ja mis allikad on usaldusväärsed.

\subsubsection{Tõlkimise abitarkvara puudulik kasutamisoskus}

Suur osa tarbetõlkimisest toimub tänapäeval arvutipõhise tõlkena, millel on hulk eeliseid tavalise tõlkimise ees, ent ka oma erilised veapõhjused. Kui tõlkija ei loe tõlkemälust võetavaid täpseid vasteid üle, kandub seal olla võiv viga tõlgitavasse teksti (rääkimata osalistest kokkulangevustest).

Samuti juhtub sageli, et tõlkija ei oska valesti segmenteeritud lauseosi liita (kui lause keskel on punkt, koolon või semikoolon) ja tõlgib osised eraldi, hoomamata, et tegu on ühe lausega. Nt tabelipäise Correct VAT Reg. No Format for each country vasteks sai tõlkija Õige käibemaksukohuslase registreerimisnumber. Iga riigi jaoks puuduv vorming, kuigi terve alljärgnenud tabel oli registrinumbrite formaate täis.

Vihjesõnastik loetleb vasteid ilma neid seletamata, sellise sõnastiku kasutamine eeldab vastete täpse tähenduse teadmist. 


\subsubsection{Psühholoogilised tegurid}

Kuigi hooletusel on siin mingi osa, võivad muude põhjustega seletamatud tõlkevead tekkida sellepärast, et tõlkijal on kiire, ta on väsinud või on mõtted hajevil. Valestilugemise näiteid: $\log$ files $\sim$ pikad failid (p.o logifailid - tõlkija on log asemel lugenud long); system of the invention sekkumissüsteem (p.o leiutises kirjeldatud süsteem - tõlkija on invention asemel lugenud intervention); followed by the country name $\sim$ mis järgneb riigi nimele (p.o millele järgneb riigi nimi).

Peale lugemisvigade tekke võivad kirjeldatav põhjus ja muu tegevus (nt tõlke keelelise külje korduvad silumiskatsed või tugev toimetamine) pärssida ka terminipiiri tajumist ja loogilist mõtlemist, mis üheskoos võib välja viia loogikavigadeni või koguni tõlketotrusteni. Mõttejooksu võib takistada ka väsimus, mis olevat olnud kogenud tõlkija tuntud tõlkeapsu gas station 'bensiinijaam' gaasijaam tekkepõhjuseks.

Psühholoogiliste veapõhjuste hulka tuleks kindlasti arvestada ka nn silmamälu, kus teksti kauaaegsel töötlemisel silm harjub kirjapildiga ja sõnad jäävad lõpuni lugemata.

\section{Mis aitab?}

Tõlkevigu täielikult vältida ei ole võimalik. See on sama paratamatu nagu see, et häid tõlkijaid on vähe, vähem kui keskpäraseid tõlkijaid. Täielikult veatu tõlke nõue tekitab vaid asjatut stressi, soodsam oleks mõistlik kvaliteedijuhtimine (nt keskendumine raskete ja sisuvigade vältimisele).

Tõlkekvaliteedi üldise kvaliteedi parandamisel tuleb kasuks tõlkijate oskuste arendamine, eelkõige tõlketeooriavõtete rakendamine - näiteks transpositsioon ehk sõnaliigi muutmine, deverbalisatsioon ehk sõnasõnalisuse vältimine lähteteksti taotluslikku sisu moonutamata, ikoonilisus ehk vormi ja sisu vastavus (nt tegevuse ajaline edasiandmine lauses) ja relevantsuse järgimine.

Valmis tõlget saab ja tuleb keeleliselt ja sisuliselt üle vaadata (korrektuur ja toimetamine). Seda peaks alati tegema teine inimene kui teksti tõlkija - teine silmapaar ja teine pea suudab tõlke värske mõttega üle vaadata ja leiab sealt vigu, mida tõlkija ei ole tähele pannud. Keelelist korrektuuri peaks tegema keeleosav inimene (kes oskab sihtkeeles ladu- 
salt ja korrektselt väljenduda), sisulist toimetamist erialainimene, kogenud tõlkija või toimetaja.

Kui tõlgete eest tasustatakse mahu järgi, peaks sisuliselt õige ja samas ka ladus ja keeleliselt korrektne tõlge olema rohkem väärt kui kohmaka sõnastusega või sõnavahuga pikaks aetud tõlge.

Tõlkija professionaalsust aitab suurendada tõlkimiseks vajalike oskuste süvendamine. Eelkõige tuleb arendada lähtekeele oskusi (et täpselt saada aru lähtetekstist), väljendusoskust sihtkeeles, valdkonnateadmisi ja allikakriitilist meelt (kuidas termini- ja teabeallikaid võib usaldada) (Fraser, Titchen Beeth 1999: 11-12). Kasuks tuleb ka üldise silmaringi laiendamine, sh lähte- ja sihtkeele erinevuste osas, et tunda sagedaid tõlkekarisid, samuti muude keelte tundmine.

Tõlgitakse sageli suure vaimse pinge all, kusjuures eri tööde puhul võivad selle pinge tekitada eri tegurid (nt tähtaeg, kvaliteet, välised häiretegurid). Tõlkijale tuleb kasuks, kui ta arendab endas järgmisi psüühilisi võimeid: süvenemisvõime, kriitikameel, avatus, keskendumisvõime, lõõgastumisvõime, tähelepanu pööramine üldpildile ja tähelepanu pööramine üksikasjadele (Fraser, Titchen Beeth 1999: 4). Tõlkevigade vältimisel on olulisim tõlkijate kaasamõtlemise ja kujutlusvõime arendamine, sest seda jääb pahatihti vajaka.

Võib tunduda, et tõlkevead ei oma erilist tähtsust, kui tõlkest on võimalik veel aru saada, elu läheb ka tõlkevigadega edasi. Semiootikud väidavad, et kogu kultuur on tõlge. Kuivõrd midagi väga tõlkeprotsessi sarnast toimub kogu eluslooduse pärilikkuse kandja DNA paljunemisel, võib väita ka, et kogu elusloodus on tõlge - ja DNA "tõlkimise" kvaliteedist oleneb see, milline on iga üksiku elusolendi käekäik. See võib olla hea vaid siis, kui tõlkevigu on tähtsusetult vähe. 


\section{Viited}

EE 2002 = Eesti Entsüklopeedia 11. Eesti üldosa. Tallinn: Eesti Entsüklopeediakirjastus. Fraser, Bill 1998. The new rhetoric: how discourse analysis can help translators. http:// europa.eu.int/comm/translation/reading/articles/pdf/1998_tp_new_rhetoric_ fraser.pdf (29.08.2004).

Fraser, Bill \& Titchen Beeth, Helen 2001. The hidden life of translators: the quest for the roots of quality. http://europa.eu.int/comm/translation/reading/articles/pdf/ 2001_hidden_life_of_translators.pdf (29.08.2004).

Le mot juste 2002 = Le mot juste: a list of terms frequently misused in the European institutions. 15.10.2002. (Fight the Fog.) http://europa.eu.int/comm/translation/ en/ftfog/motjuste.htm (29.08.2004).

Liivaku, Uno 2001. Väike soovitussõnastik. Tallinn: Eesti Keele Sihtasutus.

Martínez Melis, Nicole \& Hurtado Albir, Amparo 2001. Assessment in translation studies: research needs. - META 46, 272-287. (http://www.erudit.org/revue/ meta/2001/v46/n2/003624ar.pdf (29.08.2004).)

Nida, Eugene A. 2000. Translators' confrontations with false ideas about language. http://europa.eu.int/comm/translation/reading/articles/pdf/2000_tp_nida.pdf (29.08.2004).

Tarbijakaitseseadus - Elektrooniline Riigi Teataja. 15.04.2004. https://www.riigiteataja. ee/ert/act.jsp?id=715202 (29.08.2004).

Valdre, Andres 2004. Inglise-eesti tehnikatõlke vead. Tartu Ülikool, filosoofiateaduskond, germaani-romaani filoloogia osakond. Magistriprojekt. Tartu.

ÕS $1999=$ Eesti keele sõnaraamat ÕS 1999. Toim Tiiu Erelt, koost Tiina Leemets, Sirje Mäearu, Maire Raadik ja Tiiu Erelt. Tallinn: Eesti Keele Sihtasutus.

Ørsted, Jeannette 2001. Quality and efficiency: incompatible elements in translation practice? - META 46, 438-447. (http://www.erudit.org/revue/meta/2001/v46/ n2/003766ar.pdf (29.08.2004).) 


\section{Mistakes in English-Estonian technical translation}

ANDRES VALDRE

The article is based on a database of 918 genuine translation mistakes collected by the author during editing of raw (unedited) professional translations. Translation mistake is defined as a mismatch between the target and source texts, especially one which affects the meaning and is created during the translation process.

Eight basic groups of translation mistakes can be identified:

1. target language mistakes (mistakes independent of the translation process);

2. theme-rheme mistakes;

3. category mistakes (such as the misuse of translations of 'high' and 'low' as literal translation from English);

4. stylistic mistakes;

5. terminology mistakes;

6. wording mistakes (with minor shifts in meaning);

7. literal translations of words and grammar (accounting for $51 \%$ of the causes in the database); and

8. logical mistakes (major shifts in meaning, incl. absurdities).

The causes can be divided into two major groups: objective (independent of the translator) and subjective causes (dependent on the translator).

1. Objective causes are:

1.1. an insufficient translation brief;

1.2. non-coherent source text;

1.3. source text mistakes;

1.4. dictionary mistakes; and

1.5. spelling mistakes.

2. Subjective causes include:

2.1. the misidentification of terms;

2.2. factual mistakes;

2.3. words resembling nonrelated words in the target language;

2.4. errors in term creation;

2.5. insufficient command of source language (vocabulary, constructions, idioms);

2.6. insufficient logic; 
2.7. inconsistent use of dictionaries and termbases;

2.8. insufficient command of translation software; and

2.9. psychological causes (e.g. reading errors, fatigue).

As the main cause of bad translations is insufficient logic, and as the most frequent mistake types are literal translations and logic mistakes, any translation would benefit from a thorough consideration of whether the words of the translation really carry the intended meaning, while maintaining a clear and understandable wording in the target language.

ANDRES VALDRE (1970) on lõpetanud Helsingi Tehnikaülikooli materjaliteaduse eriala tehnikamagistrina (1994) ja tehnikalitsentsiaadina (2003). Kaitses 2004. aastal teise magistrikraadi Tartu ülikoolis kirjaliku tõlke erialal. Tegeleb tehnikatekstide tõlkimise-toimetamisega 2000. aastast; alates 2003. a töötab tõlkebüroos Eurologos-Tallinn Galandrex OÜ. Alates 2004. aastast õpetab Tallinna Pedagoogikaülikooli kirjaliku tõlke magistriõppes tehnikatõlget.

andres@valdre.com 